\title{
THE IMPACT OF SELECTED ROAD PROJECTS ON CHANGES IN TRAFFIC INTENSITY
}

\author{
Piotr Rosik, Slawomir Goliszek \\ Institute of Geography and Spatial Organization \\ Polish Academy of Sciences \\ Twarda St. 51/55, 00-818 Warsaw, Poland \\ rosik@twarda.pan.pl,sgoliszek@twarda.pan.pl \\ Karol Kowalczyk \\ Faculty of Earth Sciences and Spatial Management \\ Maria Curie-Skłodowska University \\ Kraśnicka Av. 2 cd, 20-718 Lublin, Poland \\ karol.kowalczyk@poczta.onet.pl
}

\begin{abstract}
The analysis of the influence, exerted by the road projects on traffic intensity, was performed for the period 2000-2010 on the basis of data on the intensity of traffic of passenger cars and heavy good vehicles over the network of out-of-town national and provincial roads. An abrupt increase of the number of cars and the initiation of the intensive infrastructural undertakings contributed to an essential increase in the intensity of road traffic in Poland. Opening of a motorway or of an expressway entails a shift of a part of traffic, especially of a part of the transit traffic, from the parallel national roads over to the newly constructed road segments. A motorway has, in comparison with the parallel national road, an important competitive time-wise edge, but the situation gets complicated when a motorway fee is introduced. Local factors also exert a significant influence on the changes in traffic intensity.
\end{abstract}

Keywords: traffic intensity, passenger vehicle traffic, heavy good vehicle traffic, road fees.

\section{Introduction}

The influence, exerted by the road construction projects on traffic intensity can be analysed only in a dynamic perspective ${ }^{1}$. That is why the analysis, here reported, was carried out for the period 2000-2010, this time span resulting from the data availability (lack of consistent data for the entire road network available for the period after the year 2010). The study at the national level was performed on the basis of data on traffic intensity over the network of national and provincial roads, excluding the towns having the county rights, these data being processed and gathered by the company "Transprojekt Warszawa" Ltd., upon the commission from the General Board of National

1 The paper presents the findings from the research project under the grant agreement no. NN 306564940 financed with the resources from the National Science Center. 
Roads and Motorways (GDDKiA) in the five-year cycle (starting with 1970 until the last analysis of 2010) (Generalny Pomiar Ruchu 2000, 2010). The so-called General Traffic Measurements, including those from the years 2000 and 2010, served to develop the database, referred to as "TRRAPS XXI database" (Transport Road and Railway Activity in the Polish Space in the XXI Century), which is the set of more than ten thousand records (Rosik 2014; Rosik et al. 2014; Rosik \& Kowalczyk 2015). Each record in the base corresponds to a segment of the surface road network, described with the maximum possible number of data, concerning the vehicle traffic flows (derived from the General Traffic Measurements of GDDKiA). The results are presented in the cartographic form (the stripe width map), showing the changes in traffic intensity over the road network, first of all in the framework of the case studies, but also on the national level. On the national level the distinction was made of the traffic intensity of passenger vehicles (passenger cars, coaches, microbuses, and motorbikes) and the intensity of heavy good vehicle traffic (delivery cars, trucks with and without trailers) on the network of out-of-town national and provincial roads in 2010. At the level of the case studies the intensity of total traffic and of the traffic of heavy good vehicles was analysed.

For each of the case studies four maps were presented:

- total traffic intensity in 2010 ;

- intensity of traffic of heavy good vehicles in 2010;

- changes in total traffic intensity between 2000 and 2010;

- changes in the traffic of heavy good vehicles between 2000 and 2010.

Both on the national level and in the framework of the case studies the changes in traffic intensity were analysed in the context of investment projects, related to the road network, first of all the projects, concerning the motorways and the expressways. The most important projects, realised in the years 2000-2014, considered in the framework of the case studies, are characterised in Table 1.

Table 1. The most important projects considered in the framework of case studies, years 2000-2014

\begin{tabular}{|c|c|c|}
\hline Case study & Most important projects & Date of putting into operation \\
\hline $\begin{array}{l}\text { A1 Pruszcz } \\
\text { Gdański-Grudziądz }\end{array}$ & $\begin{array}{l}\text { Construction of the motorway between the } \\
\text { nodes of Swarożyn and Nowe Marzy; } 63.5 \\
\mathrm{~km} ; 2005-2008\end{array}$ & 17.10.2008 \\
\hline $\begin{array}{l}\text { DK91 Pruszcz } \\
\text { Gdański-Grudziądz }\end{array}$ & - & - \\
\hline A4 Wrocław-Opole & $\begin{array}{l}\text { Wrocław Bielany-Owczary (Brzeg)- } \\
\text { Przylesie (Brzeg)-Prądy (Opole West) }\end{array}$ & 2000 (modernisation) \\
\hline DK94 Wrocław-Opole & - & - \\
\hline $\begin{array}{l}\text { DK8s Kudowa } \\
\text { Zdrój-Wrocław }\end{array}$ & - & - \\
\hline DK8n Augustów-Budzisko & Ring road of Augustów (S61) & 7.11.2014 \\
\hline S8 Radzymin-Wyszków & $\begin{array}{l}\text { Ring road of Radzymin; } 6.6 \mathrm{~km} \\
\text { Radzymin-Wyszków; } 17.3 \mathrm{~km} \\
\text { Ring road of Wyszków; } 12.8 \mathrm{~km}\end{array}$ & $\begin{array}{l}\text { 1998 (modernisation 2006-2007) } \\
31.07 .2009 \\
14.11 .2008\end{array}$ \\
\hline DK17 Garwolin-Kurów & Ring road of Garwolin; $12.8 \mathrm{~km}$ & 26.09 .2007 \\
\hline
\end{tabular}

Source: own elaboration. 


\section{Traffic intensity on the network of the out-of-town roads in Poland in the years 2000-2010}

The last traffic measurement in Poland, performed on the network of the out-of-town national and provincial roads in 2010 , demonstrated that the daily mean traffic intensity on the motorways was 23300 vehicles, while it did not exceed 20000 per day on the expressways. Traffic is particularly dense within the agglomerations (of Warsaw, Upper Silesia, Tri-City, Poznan, Wrocław, Cracow, and Lodz), and on the road segments leading to such agglomerations - used primarily by persons, commuting to jobs in large urban centres with their own transport means. In the setting of corridors, high traffic intensity of passenger vehicles characterised, first of all, the corridor between Warsaw, Katowice and the border with Czechia (DK8/S8/DK1/S1/A1), followed by the route of the motorway A4 (in principle, over its entire length, from the node of Krzyżowa to Przemyśl, where the average number of vehicles per day exceeds 15 000), and also, though to a lesser extent, the motorway A2 between Poznań and Konin, as well as DK7/S7 on the segments between Płońsk and Jędrzejów and between Elbląg and Gdańsk (more than 10000 passenger vehicles per day). In the year 2010 the lack of the segment of the motorway A2 between Lodz and Warsaw resulted also in a high traffic intensity on the national roads nos. 14/92 between Stryków, Łowicz and Warsaw (Fig. 1).

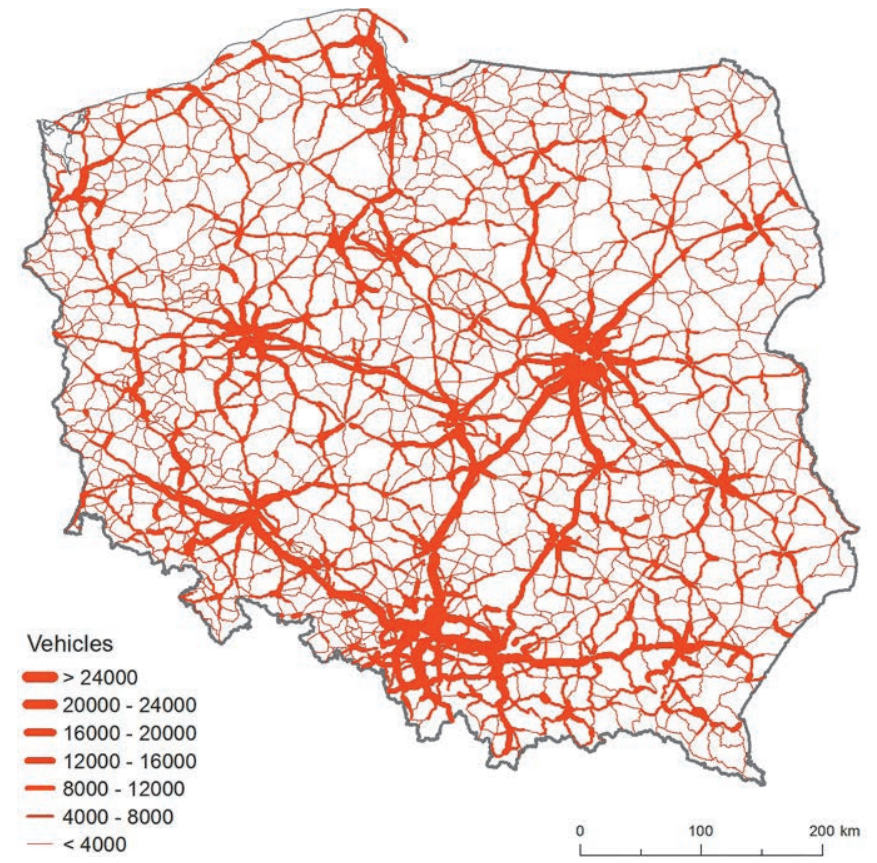

Figure 1. Intensity of traffic of passenger vehicles (passenger cars, coaches, microbuses, and motorbikes) on the network of out-of-town national and provincial roads in 2010

Source: own elaboration on the basis of GPR 2010.

On the scale of the entire network of the out-of-town national and provincial roads the intensity of traffic increased altogether in the years $2000-2010$ by approximately $42 \%$. This increase was, however, uneven over the country as a whole. In the absolute numbers, the intensity of traffic of 
passenger vehicles increased distinctly, and particularly so on the entry roads to Warsaw, within the Upper Silesian Industrial District, in the agglomeration of Cracow (including the traffic having arisen on the newly opened fragments of the A4 motorway between Gliwice and Katowice, and the motorway ring road of Cracow together with the segment Cracow-Szarów), on the ring road of the Tri-City (a fragment of S6 route), on the motorway ring road of Poznan and on the entire segment of A2 motorway between Nowy Tomyśl and Września, constructed in the years 2003-2004, as well as on the route of DK7/S7 between Warsaw and Radom, modernised and adapted to the expressway standards during the decade in question. Yet, especially characteristic is the very high increase of significance of the motorway A4, where on the majority of its course from the boundary with Germany to Cracow the average daily traffic of the passenger cars increased in the period considered by more than ten thousand vehicles.

The segments of the motorways, constructed in the years 2000-2010, brought a shift of a part of traffic (mainly concerning the longer travels, but also a portion of the local ones) from the parallel national roads, which remained two-way roads. Such a situation arose along the corridor of A4/DK94 over the segment between Wrocław and Upper Silesia, and also over the segment ZgorzelecKrzyżowa. A similar phenomenon appeared on the motorway A2 between Konin and Łowicz, where drivers take advantage of the constructed segment of the A2 motorway between Konin and Stryków (following then the national road no. 14 towards Łowicz). An analogous situation occurred on the northern fragment of the A1 motorway between the Tri-City and Grudziądz (Fig. 2).

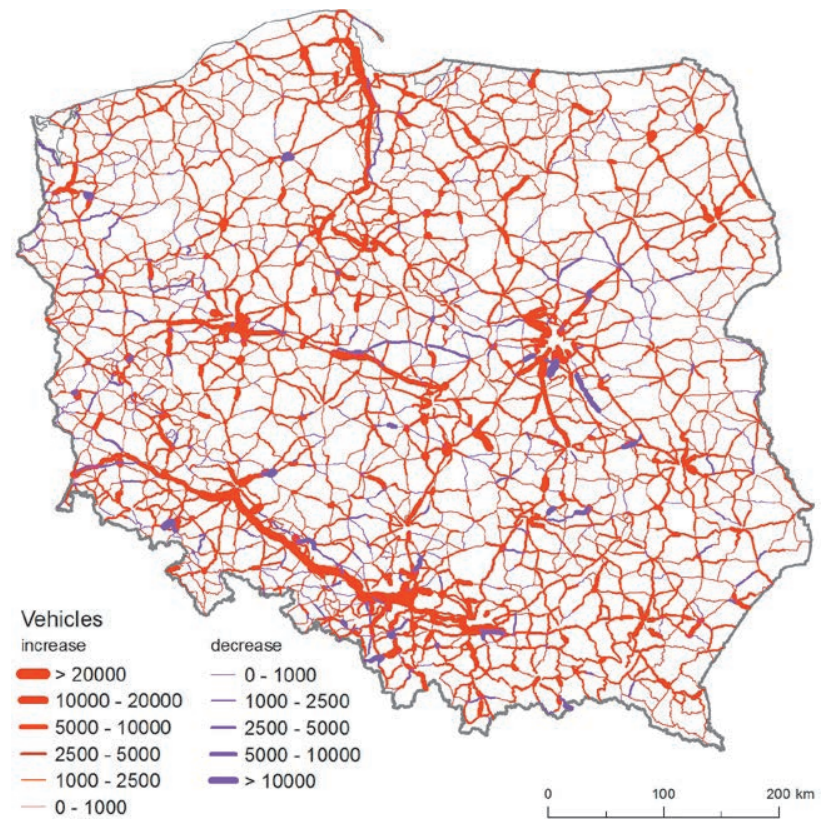

Figure 2. Changes in the daily averages of passenger vehicle traffic (passenger cars, coaches, microbuses, motorcycles) within the network of out-of-town national and provincial roads in the years 2000-2010 (red colour: increase; violet colour: decrease)

Source: own elaboration on the basis of GPR 2000 and GPR 2010. 
Traffic of trucks (light delivery vans, heavy good vehicles with and without trailers) was in 2010 distinctly concentrated along the routes of A2 and A4 motorways (traffic intensity exceeding over the majority of segments 10000 vehicles per day). The highest daily average of the heavy good vehicles traffic intensity was observed on the segment of A1 motorway in Piotrków Trybunalski (more than 19000 trucks, including more than 12000 heavy good vehicles with trailers). High intensity of the heavy good vehicles traffic characterised, as well, the diagonal setting of routes from the border with Lithuania, in Budzisko, through Warsaw, towards the South, over the roads DK8/S8/DK1/A1/S1, up to the border with Czechia. Attention ought to be paid to the high shares of the heavy good vehicle traffic, in the province of Podlasie, on two national roads, leading to the border crossing point in Budzisko (DK8 and DK61), on DK50/DK62 around Warsaw, on DK7/S7 (primarily over the segment between Warsaw and Kielce), as well as along the routes of the roads S3/DK3 and A1/DK1. The absence of the expressways and motorways in Eastern Poland results in the distribution of the heavy good vehicles traffic over numerous local roads there, while in Western and Central Poland this kind of traffic is clearly concentrated on the main motorway routes (Fig. 3).

This concentration of the heavy good vehicles traffic on the main motorway routes is particularly visible on the border-adjacent segments. On the border-adjacent segment in Świecko, which is characterised by the highest intensity of heavy good vehicles traffic, the number of trucks with trailers (more than 8000 vehicles) exceeded the number of passenger cars, crossing the boundary of the state. A similar situation took place in Budzisko, where the total number of 4500 trucks was close to twice as big as the number of passenger cars. On the other hand, in the agglomerations and on the entry roads to large cities, where traffic of trucks is often limited, their share in total traffic is relatively lower in relation to the traffic of passenger cars (Fig. 3).

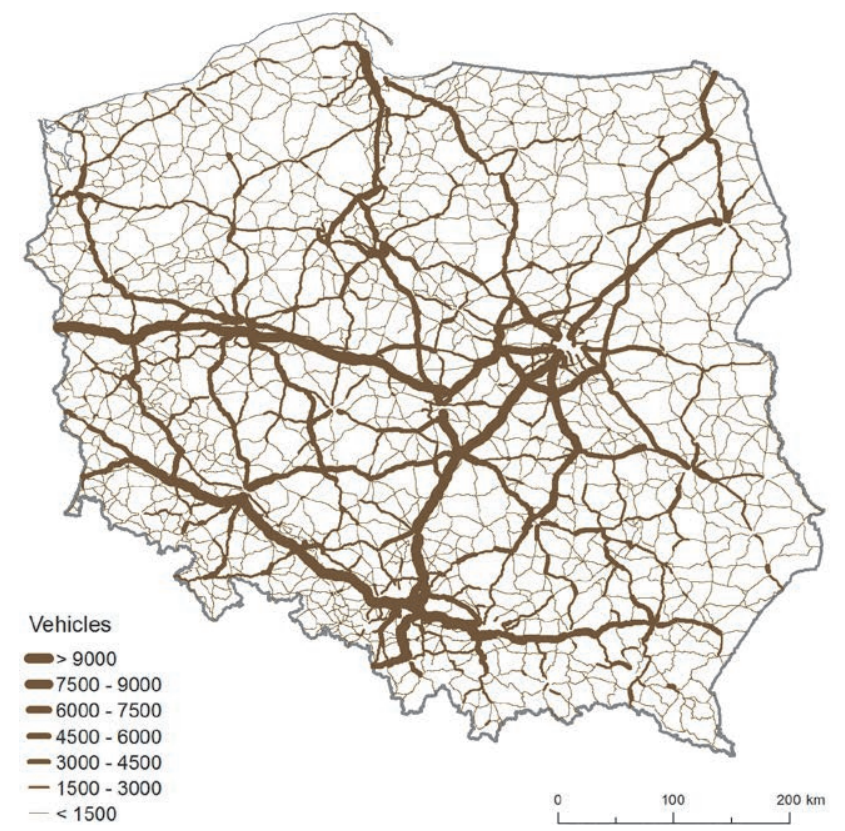

Figure 3. Intensity of traffic of heavy good vehicles (delivery vans, heavy good vehicles with and without trailers) on the network of out-of-town national and provincial roads in 2010

Source: own elaboration on the basis of GPR 2010. 
Traffic of trucks has been increasing at a very high rate in the years 2000-2010. A particularly dynamic increase was observed in the group of heavy good vehicles with trailers (increase of share in total traffic intensity from $10 \%$ in 2010 to $14.8 \%$ in 2010 , see GPR, 2010). In the first decade of the $21^{\text {st }}$ century strong concentration was taking place of the heavy good vehicles traffic on the main motorway routes (first of all A4 and A2) and within the diagonal pattern of routes from the border with Lithuania, over the setting of roads DK8/DK61, the national roads DK50/DK62 around Warsaw and the setting of DK8/DK1/S1, in the direction of the border with Czechia. Traffic concentration concerned, first of all, the heavy good vehicles with trailers (Fig. 4). Traffic intensity increased significantly on the road segments, leading to the border crossing points, allowing for the passage of trucks, along the borders with Germany, Czechia, and Lithuania, this concentration being especially pronounced at the selected, most important border crossing points.

Due to investments into infrastructure and the organisational changes, a decrease was observed in the years 2000-2010 of the heavy good vehicles traffic on some segments of the road network. Such a situation took place on the national roads, parallel to the constructed segments of the motorways, that is: between Nowy Tomyśl and Września and between Konin and Łowicz (on the national road no. 92, parallel to the newly constructed segments of the motorway A2), between Gdańsk and Grudziądz (on the national road no. 91, parallel to the new motorway A1), and from Zgorzelec to Krzyżowa node, between Wrocław and Gliwice, as well as between Cracow and Szarów (on the national road no. 94 along the work underway on the motorway A4).

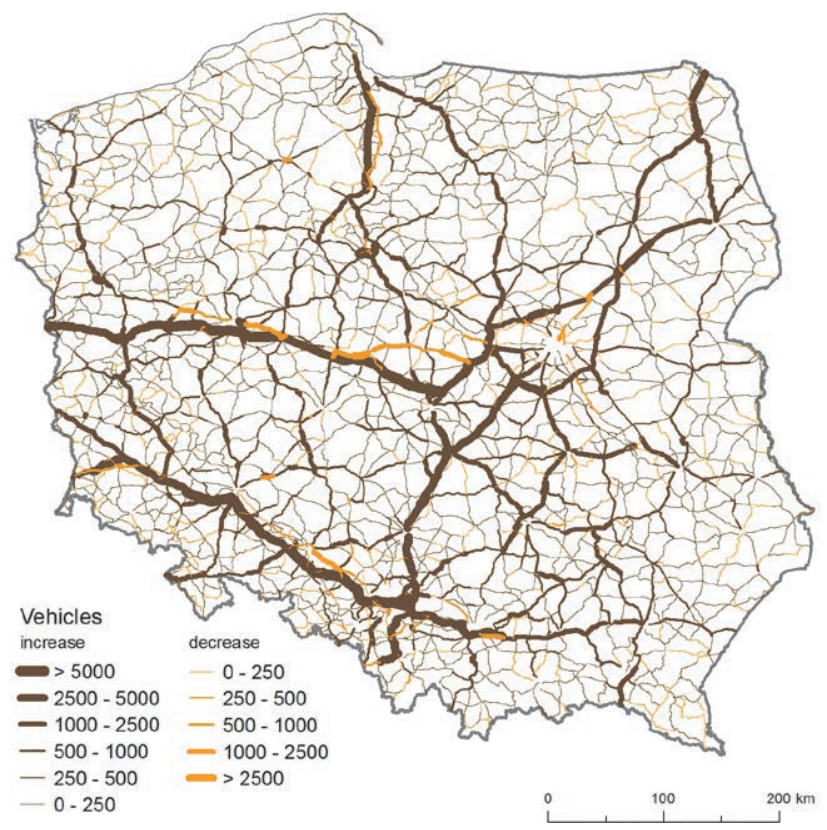

Figure 4. Absolute changes in the intensity of the traffic of trucks (delivery vans, heavy good vehicles with and without trailers) on the network of the out-of-town national and provincial roads in the years 2000-2010

(brown: increases, yellow: decreases)

Source: own elaboration on the basis of GPR 2000 and GPR 2010. 


\section{Traffic intensity on A1 motorway and the national road no. 91 between Gdansk and Grudziądz}

The segment of the motorway A1, opened in October 2008, between Rusocin (Gdańsk) and Nowe Marzy (Grudziądz) belongs to the central portion of the TEN-T corridor Baltic-Adriatic. In the year 2010, when the most recent comprehensive analysis of traffic intensity was carried out in the framework of the General Traffic Measurement, the here considered segment was the only one, which existed in the framework of the central segment of the TEN-T corridor. The lack of the remaining segments - meaning lack of the network effect - could influence to a large extent the outcome from the analysis.

Besides, the character of traffic over this segment of the route is highly differentiated, depending upon the season of the year and the day of the week, in view of the holiday and vacation travels to and from the Polish seaside. Thus, for instance, in the light of the traffic study of 2010, the average traffic intensity on the segment between Rusocin and Łęgowo amounted to slightly more than 10000 vehicles, while in July 2014, on the same segment, the average daily traffic was 54500 vehicles, and

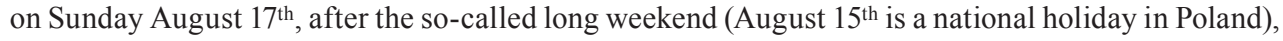
93000 cars passed this segment in a day. The so high traffic intensity results in the problem with gigantic lines at the toll gates, serviced by the private concessionary - Gdańsk Transport Company (GTC). In any case, the intensity of traffic exceeding 50000 vehicles per day may even imply the necessity of constructing the third lane on the northern segment of the A1 motorway, where, side by side with the long-distance traffic, including the vacation-related travels, an important local traffic of commuters to the Tri-City also takes place.

It is worth adding that in spite of the introduction of the motorway toll on the segment of A1 motorway between Rusocin and Nowe Marzy in the years 2008-2009, only a part of drivers would opt at the end of the decade considered to take, instead, over the same segment, the newly repaired alternative national road no. 91. Traffic on this parallel road significantly dropped, together with a significant decrease in the traffic of heavy good vehicles with trailers, this being the confirmation of the proposition that after the segments of the motorways are opened, even if they are paid, a transfer occurs of an important part of traffic from the parallel national roads (see Tab. 2 and Figs. 5 and 6). 
Table 2. Traffic intensity in 2010 on the segment of A1 motorway between Rusocin (Gdansk) and Nowe Marzy (Grudziądz) and on the parallel national road no. 91 between Gdansk and Grudziądz

\begin{tabular}{|c|c|c|c|c|c|c|c|c|c|}
\hline $\begin{array}{c}\text { Road } \\
\text { no. }\end{array}$ & $\begin{array}{l}\text { Length } \\
(\mathbf{k m})\end{array}$ & Segment & $\begin{array}{l}\text { Total of } \\
\text { vehicles }\end{array}$ & $\begin{array}{l}\text { Motor- } \\
\text { cycles }\end{array}$ & $\begin{array}{c}\text { Passen- } \\
\text { ger cars, } \\
\text { micro- } \\
\text { buses }\end{array}$ & $\begin{array}{c}\text { Light } \\
\text { trucks } \\
\text { (delivery } \\
\text { vans) }\end{array}$ & $\begin{array}{c}\text { Heavy } \\
\text { good } \\
\text { vehicles } \\
\text { without } \\
\text { trailers }\end{array}$ & $\begin{array}{c}\text { Heavy } \\
\text { good } \\
\text { vehicles } \\
\text { with } \\
\text { trailers }\end{array}$ & Coaches \\
\hline \multicolumn{10}{|c|}{ A1 motorway } \\
\hline A1 & 16.0 & $\begin{array}{l}\text { Rusocin node } \\
\text {-Stanisławie Node }\end{array}$ & 15536 & 26 & 11183 & 729 & 544 & 2991 & 63 \\
\hline A1 & 7.7 & $\begin{array}{l}\text { Stanisławie node } \\
\text {-Swarożyn node }\end{array}$ & 14136 & 30 & 9820 & 692 & 504 & 3030 & 60 \\
\hline A1 & 12.6 & $\begin{array}{l}\text { Swarożyn node } \\
\text {-Pelplin node }\end{array}$ & 12245 & 22 & 8348 & 529 & 441 & 2857 & 48 \\
\hline A1 & 21.1 & $\begin{array}{l}\text { Pelplin node } \\
\text {-Kopytkowo node }\end{array}$ & 12437 & 22 & 8722 & 459 & 300 & 2881 & 53 \\
\hline A1 & 7.3 & $\begin{array}{l}\text { Kopytkowo node } \\
\text {-province boundary }\end{array}$ & 10599 & 22 & 6753 & 447 & 314 & 3017 & 46 \\
\hline A1 & 24.5 & $\begin{array}{l}\text { province boundary } \\
\text {-Nowe Marzy }\end{array}$ & 10599 & 22 & 6753 & 447 & 314 & 3017 & 46 \\
\hline \multicolumn{10}{|c|}{ National road no. 91} \\
\hline 91 & 2.0 & $\begin{array}{l}\text { Gdańsk-Pruszcz } \\
\text { Gdański }\end{array}$ & 13704 & 92 & 11214 & 1005 & 383 & 557 & 557 \\
\hline 91 & 3.1 & $\begin{array}{l}\text { Pruszcz Gdański } \\
\text { /passage/ }\end{array}$ & 13594 & 75 & 10846 & 918 & 558 & 888 & 888 \\
\hline 91 & 17.8 & $\begin{array}{l}\text { Pruszcz } \\
\text { Gdański-Tczew }\end{array}$ & 14185 & 56 & 11361 & 1161 & 728 & 753 & 753 \\
\hline 91 & 1.5 & Tczew /passage/ & 13153 & 75 & 10470 & 1203 & 654 & 723 & 723 \\
\hline 91 & 5.1 & Tczew-Czarlin & 15879 & 90 & 12266 & 1957 & 577 & 861 & 861 \\
\hline 91 & 13.2 & Czarlin-Rudno & 8054 & 52 & 6029 & 767 & 488 & 621 & 621 \\
\hline 91 & 12.3 & Rudno-Gniew & 6309 & 31 & 4448 & 735 & 374 & 640 & 640 \\
\hline 91 & 10.9 & Gniew-Rakowiec & 5418 & 40 & 3747 & 741 & 416 & 411 & 411 \\
\hline 91 & 2.3 & $\begin{array}{l}\text { Rakowiec-Kolonia } \\
\text { Ostrowicka }\end{array}$ & 4994 & 40 & 3462 & 699 & 303 & 440 & 440 \\
\hline 91 & 9.7 & $\begin{array}{l}\text { Kolonia } \\
\text { Ostrowicka-Nowe } \\
\text { Marzy }\end{array}$ & 4672 & 37 & 3111 & 711 & 344 & 424 & 424 \\
\hline
\end{tabular}

Source: own elaboration. 

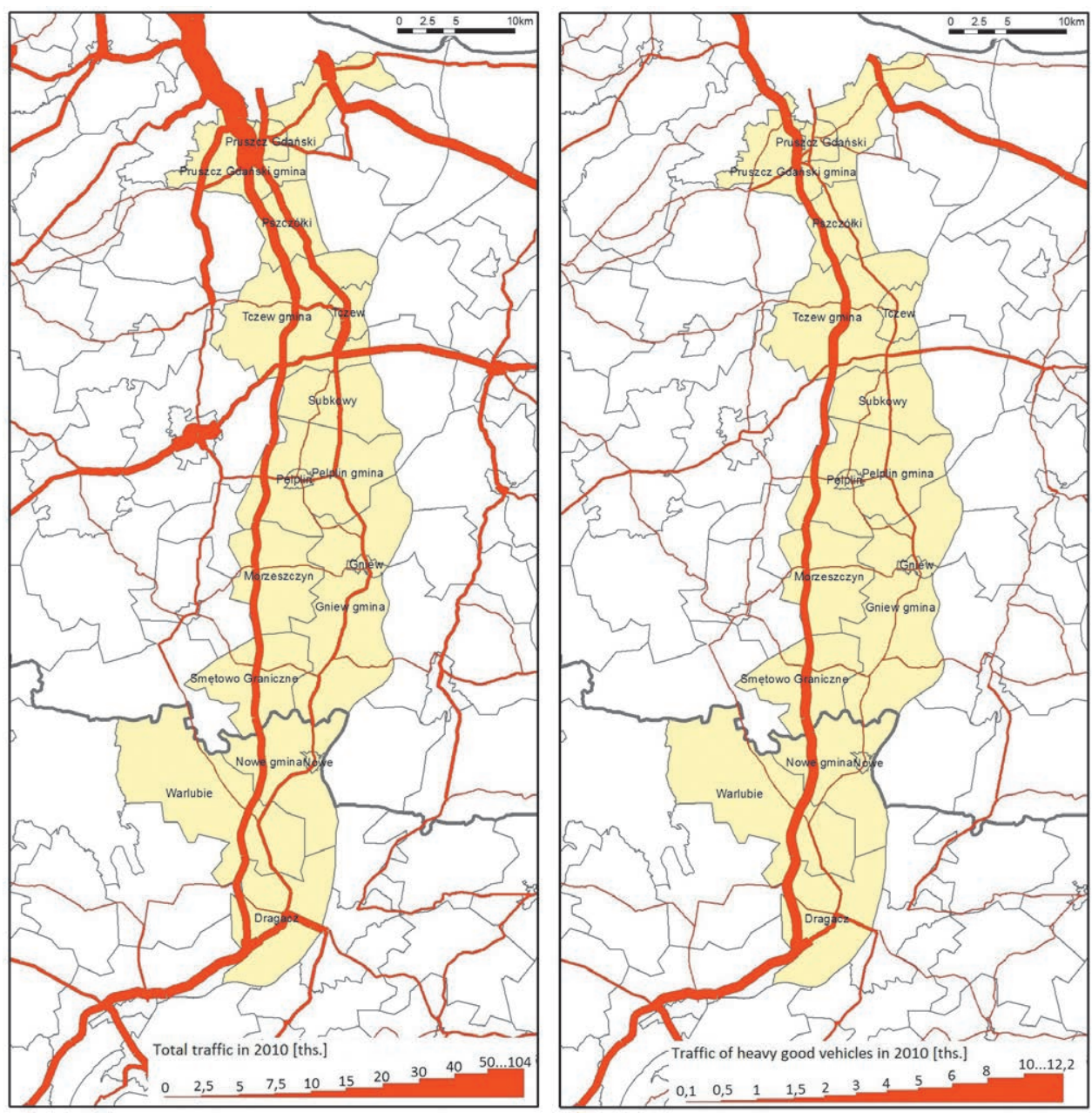

Figure 5. Total vehicle traffic intensity and heavy good vehicle traffic intensity in 2010 on the segment of A1 motorway between Rusocin (Gdansk) and Nowe Marzy (Grudziądz) and on the parallel national road no. 91 between Gdansk and Grudziądz

Source: own elaboration on the basis of GPR 2010. 

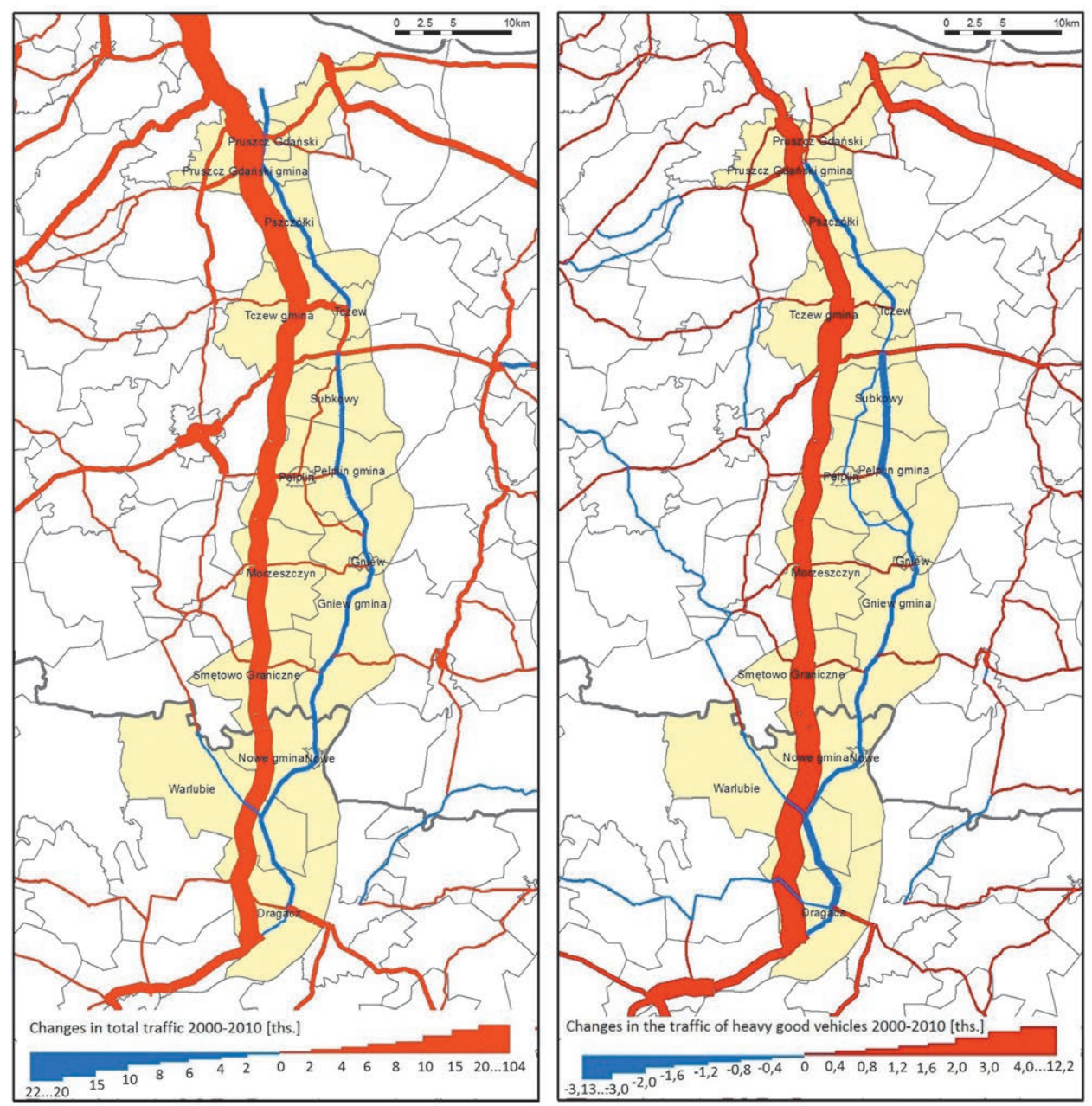

Figure 6. Changes in the total traffic intensity and in the intensity of heavy good vehiclestraffic in the years 2000-2010 on the segment of A1 motorway between Rusocin (Gdansk) and Nowe Marzy (Grudziądz) and on the parallel national road no. 91 between Gdansk and Grudziądz

Source: own elaboration on the basis of GPR 2000 and GPR 2010.

\section{Traffic intensity on the A4 motorway and on the national road no. 94 between Wroclaw and Opole}

The here analysed segment of the A4 motorway between Wrocław (Bielany Wrocławskie) and Opole (Dąbrówka node) was modernised over the length of more than $90 \mathrm{~km}$ in December 2000. In the following years, 2001-2005, the consecutive segments of the A4 motorway were opened in the direction of Upper Silesia (including the segments Dąbrówka-Nogawczyce in 2001, Nogawczyce-Kleszczów in 2003, and Kleszczów-Sośnica-Chorzów in 2005), which had a very important influence on the realisation of the network effect and the possibility of achieving a smooth transit without paying the 
toll already since the year 2005. Generally, the intensity of traffic in the entire southern part of the TEN-T corridor Baltic-Adriatic on its Polish fragment, specifically on the segment between Legnica and Upper Silesia, is particularly high, this being the outcome of the superposition of the local traffic within this relatively densely populated territory and the increasingly important transit traffic along the course of A4 motorway. The average daily traffic intensity on the motorway A4 between Wrocław and Gliwice ranged in 2010 between 25000 and 37000 vehicles. The concentration of the traffic is so high that when in 2014 the road surface was being repaired over the segment between Wrocław and Opole, the jams would form of several kilometres of length. The intensity of traffic of heavy good vehicles with trailers was stable and very high, amounting to roughly 6-8 000 vehicles per day (Table 3).

Table 3. Traffic intensity in 2010 over the segment of the motorway A4 between Wrocław (Bielany node) and Opole (Dąbrówka Górna node) and on the parallel national road no. 94 between Wrocław and Opole

\begin{tabular}{|c|c|c|c|c|c|c|c|c|c|}
\hline $\begin{array}{c}\text { Road } \\
\text { no. }\end{array}$ & $\begin{array}{l}\text { Length } \\
\text { (km) }\end{array}$ & Segment & $\begin{array}{c}\text { Total } \\
\text { of } \\
\text { vehicles }\end{array}$ & $\begin{array}{c}\text { Motor- } \\
\text { cycles }\end{array}$ & $\begin{array}{c}\text { Passen- } \\
\text { ger cars, } \\
\text { micro- } \\
\text { buses }\end{array}$ & $\begin{array}{c}\text { Light } \\
\text { trucks } \\
\text { (delivery } \\
\text { vans) }\end{array}$ & $\begin{array}{c}\text { Heavy } \\
\text { good } \\
\text { vehicles } \\
\text { without } \\
\text { trailers }\end{array}$ & $\begin{array}{c}\text { Heavy } \\
\text { good } \\
\text { vehi- } \\
\text { cles } \\
\text { with } \\
\text { trailers }\end{array}$ & Coaches \\
\hline \multicolumn{10}{|c|}{ A4 motorway } \\
\hline A4 & 11.2 & $\begin{array}{l}\text { Bielany Wrocławskie } \\
\text { node-Krajków node }\end{array}$ & 37434 & 49 & 23974 & 3652 & 1173 & 8399 & 187 \\
\hline A4 & 14.2 & $\begin{array}{l}\text { Krajków node-Brzezimierz } \\
\text { node }\end{array}$ & 34145 & 42 & 21278 & 3340 & 1110 & 8186 & 189 \\
\hline A4 & 14.8 & $\begin{array}{l}\text { Brzezimierz node-province } \\
\text { boundary }\end{array}$ & 30735 & 33 & 18639 & 3197 & 1108 & 7592 & 166 \\
\hline A4 & 0.1 & $\begin{array}{l}\text { province boundary } \\
\text {-Przylesie node }\end{array}$ & 30735 & 33 & 18639 & 3197 & 1108 & 7592 & 166 \\
\hline A4 & 28.9 & Przylesie node-Prądy & 28606 & 36 & 16911 & 2219 & 1758 & 7519 & 163 \\
\hline A4 & 22.0 & Prądy-Dąbrówka Górna & 23379 & 32 & 13395 & 1986 & 1271 & 6588 & 107 \\
\hline \multicolumn{10}{|c|}{ National road no. 94} \\
\hline 91 & 7.4 & Wrocław-Groblice & 13363 & 54 & 10894 & 1110 & 477 & 599 & 225 \\
\hline 91 & 11.3 & Groblice-Oława & 13352 & 49 & 10968 & 1107 & 373 & 665 & 169 \\
\hline 91 & 4.3 & Oława /passage/ & 13191 & 69 & 10204 & 1082 & 394 & 1210 & 201 \\
\hline 91 & 7.0 & Oława-province boundary & 6264 & 41 & 4926 & 535 & 220 & 446 & 76 \\
\hline 91 & 3.5 & province boundary-Brzeg & 6267 & 40 & 4725 & 567 & 296 & 560 & 65 \\
\hline 91 & 2.3 & Brzeg /ring road 1/ & 6460 & 43 & 4598 & 673 & 217 & 861 & 56 \\
\hline 91 & 0.8 & Brzeg /ring road 2/ & 7297 & 47 & 5772 & 677 & 258 & 452 & 74 \\
\hline 91 & 20.2 & Brzeg-Skorogoszcz & 4321 & 26 & 3251 & 410 & 190 & 377 & 57 \\
\hline 91 & 11.5 & Skorogoszcz-Karczów & 5688 & 31 & 4577 & 487 & 194 & 326 & 61 \\
\hline 91 & 0.7 & Karczów-Wrzoski & 21462 & 67 & 16071 & 1565 & 772 & 2794 & 182 \\
\hline 91 & 5.2 & Opole /ring road/ & 11642 & 41 & 7598 & 1144 & 339 & 2441 & 62 \\
\hline
\end{tabular}

Source: own elaboration. 
Similarly as in the case of the motorway A1, the achievement of the effect of fast travel to the capital of the province (in the case of A4 - Wrockaw) resulted in the decrease of the traffic intensity on the parallel national road no. 94. Yet, concerning the traffic of passenger vehicles the decrease of intensity is visible first of all for the long travels, i.e. over the segment between Oława and Opole. The inhabitants of Oława and of the localities, situated between Oława and Wrocław, have not been willing to choose the motorway in their daily job commuting to Wrocław. The motorway option was more advantageous, on the other hand, for the longer commuter trips from the localities situated between Oława and Opole (Fig. 7). Regarding the traffic of trucks, the shift from the national road over to the motorway is visible along the entire course of the roads between Wrocław and Opole (Fig. 8).
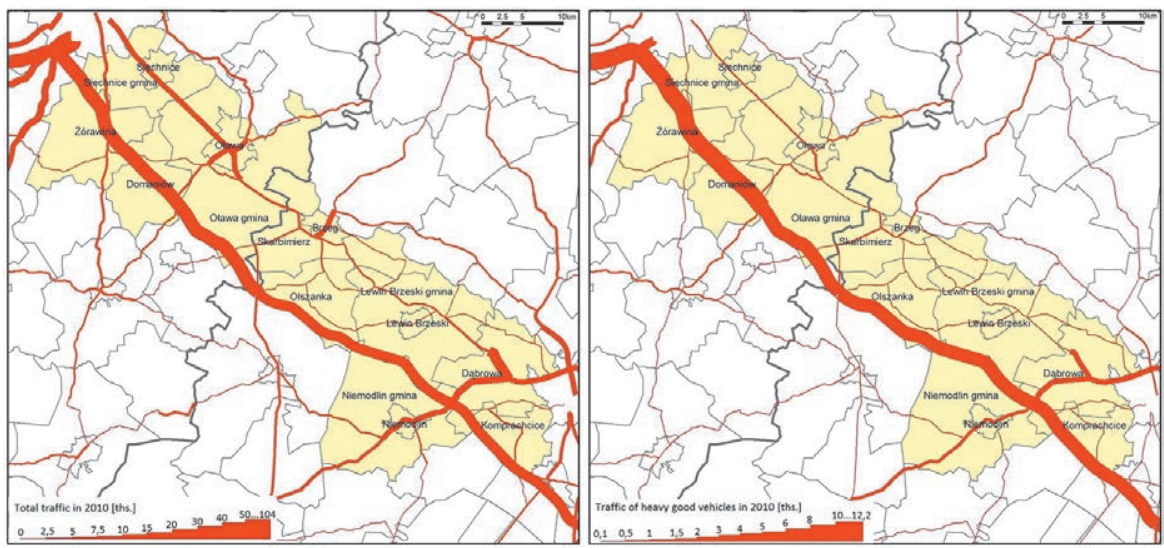

Figure 7. Traffic intensity in total and of the heavy good vehicles in 2010 on the motorway A4 between Wrocław (Bielany node) and Opole (Dąbrówka Górna node) and on the parallel national road no. 94 between Wrocław and Opole

Source: own elaboration on the basis of GPR 2010.
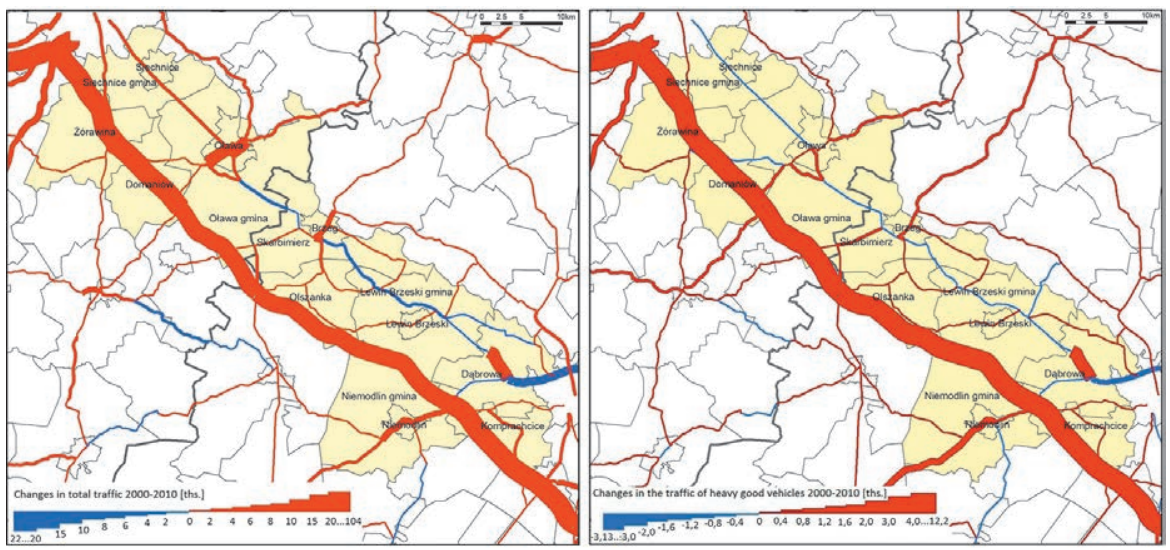

Figure 8. Changes in total traffic intensity and in heavy good vehicles traffic intensity in the years 2000-2010 on the motorway A4 between Wrocław (Bielany node) and Opole (Dąbrówka Górna node) and on the parallel national road no. 94 between Wrocław and Opole Source: own elaboration on the basis of GPR 2000 and GPR 2010. 
The intensity of traffic on the paid segments of motorways is strongly influenced by the toll costs. While in the case of the segment Rusocin-Nowe Marzy (A1 motorway) the introduction of the toll payment in 2008 might have had an influence on the reduction of traffic intensity in 2010, toll payment on the segment of the A4 motorway between Wrocław and Opole was introduced after 2010, which could result in a change of traffic intensity on the motorway at least in this portion of traffic, which is due to the daily job commuting movements. In the middle of 2012 the toll rate, provided by the motorway administrator for this segment, was 0.10 PLN per km (Table 4).

Table 4. Toll rates for passenger cars on the main motorway routes in Poland (A1, A2 and A4) in the middle of 2012

\begin{tabular}{|c|c|c|c|c|c|c|c|c|c|}
\hline \multirow[b]{2}{*}{ Road } & \multicolumn{5}{|c|}{ Distance marks* } & \multicolumn{3}{|c|}{ Toll rates ${ }^{* *}$} & \multirow[b]{2}{*}{$\begin{array}{l}\text { Admini- } \\
\text { strator }\end{array}$} \\
\hline & Initial & $\begin{array}{c}\text { Termi- } \\
\text { nal }\end{array}$ & Length & $\begin{array}{l}\text { Initial } \\
\text { node }\end{array}$ & $\begin{array}{l}\text { Terminal } \\
\text { node }\end{array}$ & $\begin{array}{l}\text { Total, } \\
\text { in PLN }\end{array}$ & $\begin{array}{l}\text { Real toll, } \\
\text { PLN/km }\end{array}$ & \begin{tabular}{|c|} 
Rate \\
provided \\
by the \\
administra- \\
tor, PLN \\
per km
\end{tabular} & \\
\hline \multirow[b]{2}{*}{ Z } & 1.1 & 90.3 & 89.2 & Rusocin & Nowe Marzy & 17.6 & 0.20 & 0.16 & \multirow{2}{*}{$\begin{array}{l}\text { Gdańsk } \\
\text { Transport } \\
\text { Company } \\
\text { S.A. }\end{array}$} \\
\hline & 90.3 & 152 & 61.7 & Nowe Marzy & Nowa Wieś & 12.3 & 0.20 & 0.16 & \\
\hline \multirow{7}{*}{ 2 } & 3 & 21 & 18 & Świecko & Rzepin & toll-free & toll-free & toll-free & \multirow{5}{*}{$\begin{array}{l}\text { Autostrada } \\
\text { Wielkopol- } \\
\text { ska S.A. }\end{array}$} \\
\hline & 21 & 107.6 & 86.6 & Rzepin & Nowy Tomyśl & 17.0 & 0.20 & 0.20 & \\
\hline & 107.6 & 159.4 & 51.8 & Nowy Tomyśl & $\begin{array}{l}\text { Poznań } \\
\text { Zachód }\end{array}$ & 14.0 & 0.27 & 0.28 & \\
\hline & 159.4 & 170.5 & 11.1 & Poznań Zachód & $\begin{array}{l}\text { Poznań } \\
\text { Wschód }\end{array}$ & toll-free & toll-free & toll-free & \\
\hline & 170.5 & 257.2 & 86.7 & $\begin{array}{l}\text { Poznań } \\
\text { Wschód }\end{array}$ & Konin Zachód & 28.0 & 0.32 & 0.28 & \\
\hline & 257.2 & 360.4 & 103.2 & Konin Zachód & Łódź Północ & 9.9 & 0.10 & 0.10 & \multirow[t]{5}{*}{ GDDKiA } \\
\hline & 360.4 & 456 & 95.6 & Łódź Północ & $\begin{array}{l}\text { Warszawa } \\
\text { Zachód }\end{array}$ & toll-free & toll-free & toll-free & \\
\hline \multirow{6}{*}{ 㐊 } & 1.8 & 153.5 & 151.7 & Zgorzelec & $\begin{array}{l}\text { Bielany } \\
\text { Wrocławskie }\end{array}$ & toll-free & toll-free & toll-free & \\
\hline & 153.5 & 296.6 & 143.1 & $\begin{array}{l}\text { Bielany } \\
\text { Wrocławskie }\end{array}$ & Kleszczów & 16.2 & 0.11 & 0.10 & \\
\hline & 296.6 & 315.9 & 19.3 & Kleszczów & Sośnica & toll-free & toll-free & toll-free & \\
\hline & 315.9 & 349.5 & 33.6 & Sośnica & Droga S1 & toll-free & toll-free & toll-free & \multirow{2}{*}{$\begin{array}{l}\text { Stalexport } \\
\text { Autostrada } \\
\text { Małopolska } \\
\text { S.A. }\end{array}$} \\
\hline & 349.5 & 401.3 & 51.8 & Droga S1 & Balice I & 18.0 & 0.35 & & \\
\hline & 401.3 & 444.9 & 43.6 & Balice I & Szarów & toll-free & toll-free & toll-free & GDDKiA \\
\hline
\end{tabular}

* After Ruch drogowy 2010

*** Detailed analysis of toll rates was carried out in the middle of 2012

Segment, constituting the object of case study

Source: own elaboration. 


\section{Traffic intensity on the national road no. 8 between Kudowa-Zdrój and Wroclaw}

Assessment of the situation regarding traffic intensity on the national road no. 8 over the segment between Wrocław and Kudowa Zdrój requires a broader consideration, concerning the Polish-Czech transport relations. Conform to the stipulations of the Concept for the Spatial Development of the Country 2030 (KPZK 2030), Polish-Czech boundary is crossed by four axes of functional interconnections, three of them having fundamental significance (Warsaw-Wrocław-Prague, LodzKatowice-Ostrava-Vienna, and Cracow-Ostrava-Prague), and one, having complementary character (Poznań-Wrocław-Brno-Vienna). There is a need for a bigger number of bilateral, Polish-Czech transport connections, which would be possibly spatially dispersed (as this takes place along the Polish-German boundary). These statements are being confirmed by the changes in the distribution of traffic intensity, which are expressed, in particular, through significant increases of the numbers of trucks, leaving Poland through Kłodzko Bowl and Kudowa in the direction of Prague. This traffic is brought there over the routes from Wrocław, but also from Opole through Nysa (see Fig. 10).

As of now, on the Polish side, connection of Polish and Czech road networks is envisaged in Lubawka, where it is intended to connect the expressway S3 with the Czech road of the same rank. Yet, in spite of the existing agreements, the Czech side is not realising currently the project to the North of the town of Hradec Kralove. Under these conditions, Polish undertakings on the southern segment of the road S3 were split into the fragment Legnica-Bolków (for which the respective tender has already been announced), and Bolków-Lubawka, the realisation of the latter remaining suspended in the expectation of the counterpart realisation by the Czech side. The very course of the southern segment of S3 gives rise to doubts, since the main prerequisite for determining this route was to channel out traffic from the expressway S3 (connection with the motorway A4 to the West of Legnica). This is a remainder of the former assumption as to the dominating transit character of the road. In reality, the pattern of the functional connections, as well as the distribution of traffic (especially of the heavy good vehicle traffic) imply that the future connection through Lubawka shall be used primarily by the diagonal traffic from the direction of Central Poland towards Prague, and further on - to South-Western Europe. Hence, the essential traffic flow shall be covering a distinctly bigger distance, leaving outside the network the industrial centres, situated at the foot of Sudety Mts., including the Special Economic Zone of Wałbrzych. The increasing role of Wałbrzych as the generator of traffic is evidenced by a high increase of the number of trucks (2005-2010) on the roads from this city to Wrocław and to Legnica (Fig. 10). These issues were noted in the Concept for the Spatial Development of the Country 2030 (KPZK 2030), in which, side by side with the expressway S3 in its current course, the connection Wrocław-Wałbrzych-Bolków is planned, having the qualities of an expressway.

From the point of view of traffic intensity on the segment between Wrocław and Kłodzko, an even bigger role appears to be played by the road exit along the direction Wrocław-Brno, through Kłodzko Bowl, postulated in KPZK 2030, and in the strategic documents of the Lower Silesian province. It is over this route that the shortest connection leads from the seaports of Szczecin towards Vienna and further to the Adriatic ports. On the Czech territory, the segment from the locality of Moravska Trebova to Brno is planned as the expressway R43 (nowadays the $1^{\text {st }}$ class road I43), and only on the segment through Dolni Lipka to Moravska Trebova (crossing Orlicke Mts.) the road I43 preserves its status of the main road also in the planning documents. At this point the stipulations of the Polish document (KPZK 2030) and of the Czech ones remain inconsistent. The roads between 
Wrocław and Bolków, and from Wrocław to Kłodzko and Brno are not accounted for, not only in the Implementation Document, but also in the Governmental Program of Construction of National Roads. It appears to be purposeful to accelerate, in particular, the second of the investment projects mentioned. At the same time, realisation of the segment up to the border crossing in Lubawka (according to the present course) should remain conditioned upon the parallel undertakings on the Czech side. Until now, though, the plans of realisation of the segment crossing Kłodzko Bowl are contained only in KPZK 2030.

Table 5. Traffic intensity in 2010 on the segment of the national road no. 8 between state boundary in Kudowa Zdrój and Wrocław (Bielany node)

\begin{tabular}{|c|c|c|c|c|c|c|c|c|c|}
\hline $\begin{array}{c}\text { Road } \\
\text { no. }\end{array}$ & $\begin{array}{c}\text { Length } \\
(\mathrm{km})\end{array}$ & Segment & $\begin{array}{c}\text { Total } \\
\text { of } \\
\text { vehicles }\end{array}$ & $\begin{array}{l}\text { Motor- } \\
\text { cycles }\end{array}$ & $\begin{array}{c}\text { Passen- } \\
\text { ger cars, } \\
\text { micro- } \\
\text { buses }\end{array}$ & $\begin{array}{c}\text { Light } \\
\text { trucks } \\
\text { (delivery } \\
\text { vans) }\end{array}$ & $\begin{array}{c}\text { Heavy } \\
\text { good } \\
\text { vehicles } \\
\text { without } \\
\text { trailers }\end{array}$ & $\begin{array}{c}\text { Heavy } \\
\text { good } \\
\text { vehicles } \\
\text { with } \\
\text { trailers }\end{array}$ & Coaches \\
\hline 8 & 3.2 & $\begin{array}{l}\text { state boundary } \\
\text {-Kudowa-Zdrój }\end{array}$ & 7256 & 59 & 4552 & 476 & 176 & 1917 & 72 \\
\hline 8 & 10.5 & $\begin{array}{l}\text { Kudowa-Zdrój } \\
\text {-Duszniki-Zdrój }\end{array}$ & 8511 & 66 & 5597 & 674 & 191 & 1828 & 140 \\
\hline 8 & 12.9 & $\begin{array}{l}\text { Duszniki-Zdrój } \\
\text {-Polanica-Zdrój }\end{array}$ & 8924 & 39 & 5953 & 714 & 217 & 1928 & 70 \\
\hline 8 & 10.5 & Polanica-Zdrój-Kłodzko & 13596 & 67 & 10148 & 906 & 304 & 2008 & 155 \\
\hline 8 & 2.7 & Kłodzko /ring road/ & 11044 & 44 & 7555 & 1011 & 350 & 2023 & 53 \\
\hline 8 & 18.6 & $\begin{array}{l}\text { Kłodzko-Ząbkowice } \\
\text { Śląskie }\end{array}$ & 10998 & 47 & 7594 & 1354 & 405 & 1470 & 121 \\
\hline 8 & 2.1 & $\begin{array}{l}\text { Ząbkowice Śląskie } \\
\text { /passage 1/ }\end{array}$ & 9801 & 45 & 6730 & 1055 & 360 & 1476 & 123 \\
\hline 8 & 1.7 & $\begin{array}{l}\text { Ząbkowice Śląskie } \\
\text { /passage 2/ }\end{array}$ & 9607 & 48 & 6615 & 1020 & 363 & 1437 & 114 \\
\hline 8 & 22.0 & $\begin{array}{l}\text { Ząbkowice Śląskie } \\
\text {-Łagiewniki }\end{array}$ & 8719 & 41 & 5869 & 1040 & 286 & 1347 & 131 \\
\hline 8 & 19.6 & Łagiewniki-Wierzbice & 13944 & 46 & 9912 & 1469 & 441 & 1774 & 298 \\
\hline 8 & 11.8 & $\begin{array}{l}\text { Wierzbice-Bielany } \\
\text { Wrocławskie }\end{array}$ & 19791 & 74 & 15389 & 1775 & 520 & 1726 & 290 \\
\hline 8 & 0.3 & $\begin{array}{l}\text { Bielany Wrocławskie } \\
\text {-Bielany Wrocławskie } \\
\text { node }\end{array}$ & 36362 & 156 & 29584 & 2827 & 785 & 2391 & 614 \\
\hline
\end{tabular}

Source: own elaboration. 

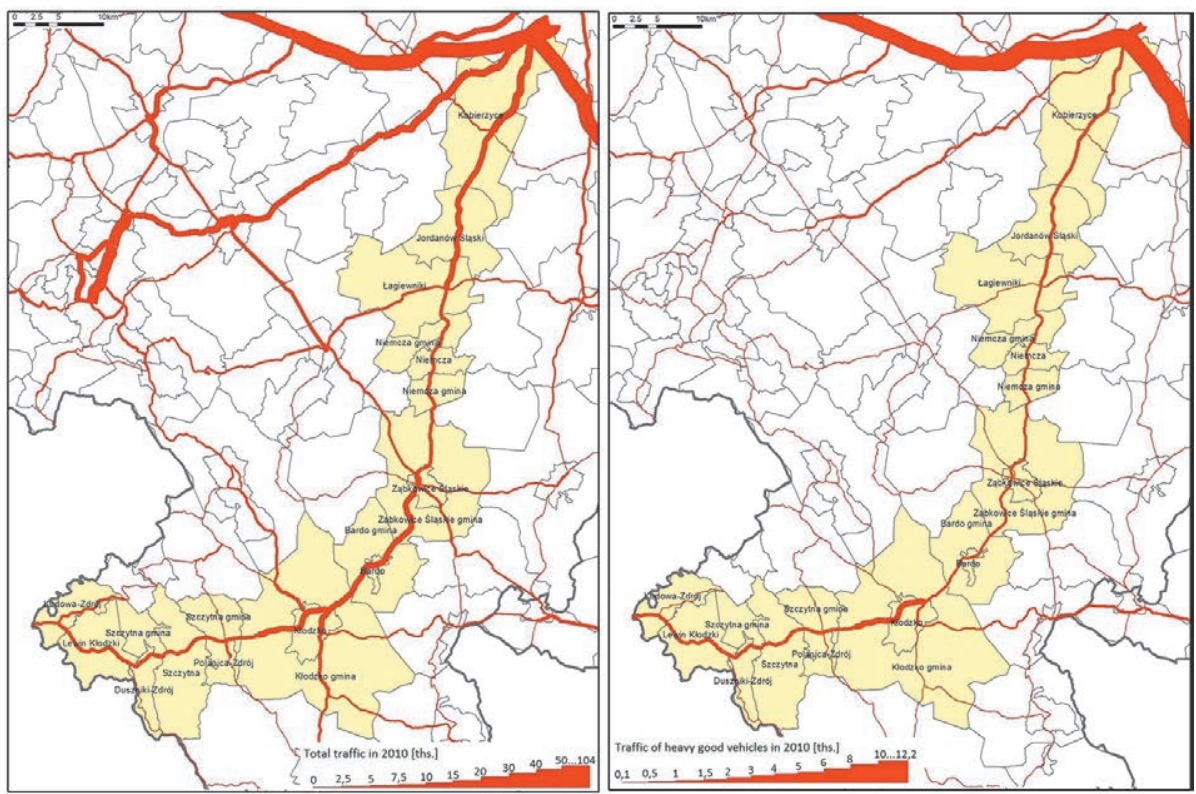

Figure 9. Traffic intensity - total and of the heavy good vehicles, in 2010 on the segment of the national road no. 8 between state boundary in Kudowa Zdrój and Wrocław (Bielany node) Source: own elaboration on the basis of GPR 2010.
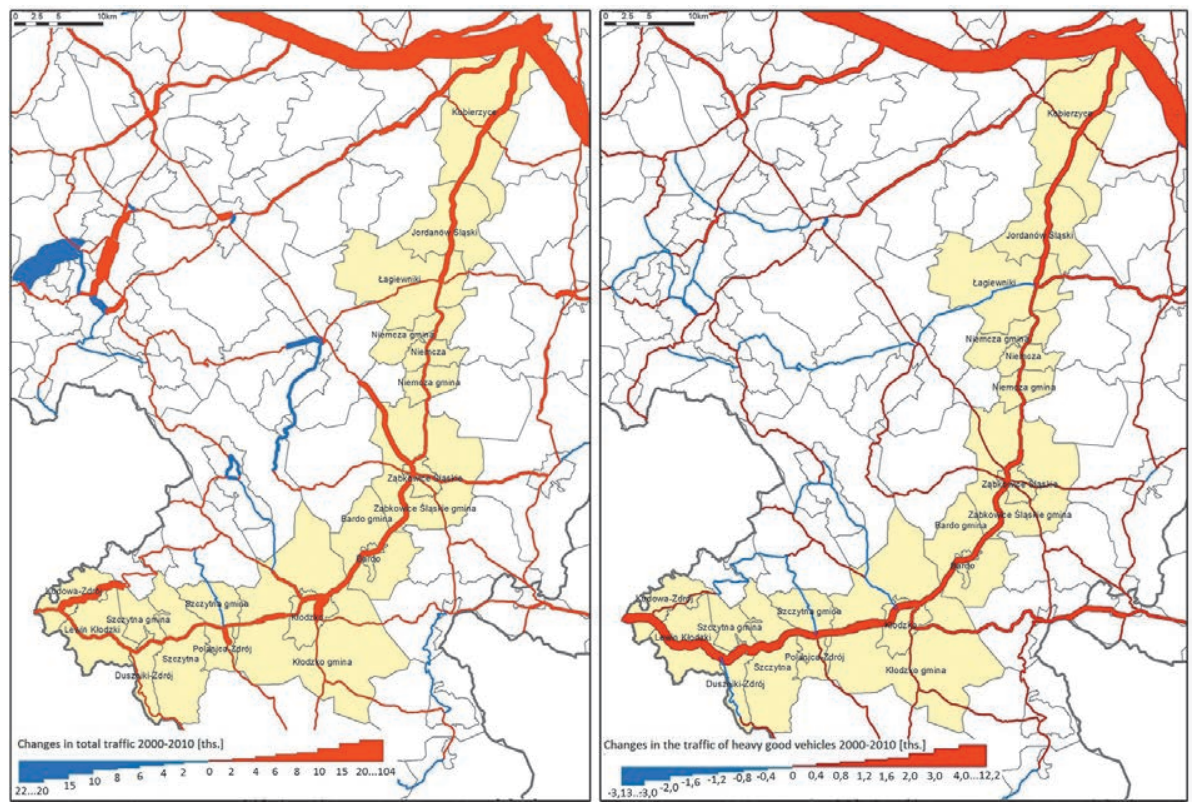

Figure 10. Changes in traffic intensity in total and of the heavy good vehicles in the years 2000-2010 on the segment of the national road no. 8 between state boundary in Kudowa Zdrój and Wrocław (Bielany node) Source: own elaboration on the basis of GPR 2000 and GPR 2010. 


\section{Traffic intensity on the national road no. 8 between Augustów and Budzisko and between Radzymin and Wyszków}

The road segments analysed belong to the north-eastern part of the TEN-T corridor North Sea-Baltic in its portion passing through the territory of Poland. The north-eastern part of the corridor leads from Warsaw to Ostrów Mazowiecka over the national road / expressway no. 8 and then over the planned expressway no. 61 in the direction of the Polish-Lithuanian border in Budzisko. The route is in the initial phase of realisation and except for the relatively short segments of S8 is the least advanced, in terms of implementation, portion of the North Sea-Baltic corridor.

The segment considered is characterised by a relatively important increase of traffic intensity. Even though the intensity of traffic in general outside of the suburban zone of Warsaw and the segment of the expressway S8 up to Ostrów Mazowiecka, as well as the passages through Łomża, Grajewo, Augustów, and Suwałki, remains, in principle below 10000 vehicles per day, this segment is characterised by a very high share of the traffic of heavy good vehicles with trailers (from 2000 up to even more than 6000 , the highest values being attained on the ring road of Ostrów Mazowiecka). An especially acute bottleneck for the inhabitants was constituted by the passage through Augustów (until November of 2014, when the ring road was opened), where two national roads, leading towards the boundary with Lithuania, DK8 and DK61, meet. The protests of the inhabitants of Augustów and Suwałki confirm the correctness of the realisation schedule of this segment of the expressway S61, starting with the ring roads of the towns of Augustów and Suwałki.

Close to fourfold increase of the traffic intensity of heavy good vehicles with trailers at the border with Lithuania in Budzisko in the years 2000-2010 (from a bit more than 1000 vehicles to more than 4000 vehicles) is an unprecedented phenomenon and an example for a very significant delay of the transport policy in relation to the geopolitical events (see Tab. 7 and Fig. 12). The access of Poland to the European Union and to Schengen zone caused that for the transport companies the direction through Lithuania to Russia turned out to be the method for avoiding one boundary (Belarusian), and, after the boundary of Schengen zone between Latvia and Russia would have been crossed - the easiest way to carry out freight transport between the European Union and Russia. It is highly probable that the intensity of heavy good vehicles traffic on the analysed direction after the year 2020 (compared to the year 2014) will significantly increase. Yet, the traffic study of 2015 may not confirm this expectation in view of the embargo, introduced by Russia in 2014, and the associated very likely transitory decrease of traffic in 2015. Currently, the analysed segment of the route between Augustów and the boundary in Budzisko, except for the ring road of Augustów, opened in 2014, is the subject of the design work (see Tab. 6). 
Table 6. The status of realisation of the road projects on the north-eastern segment of the North Sea-Baltic corridor at the end of the year 2014 (between Ostrów Mazowiecka and Budzisko at the border with Lithuania)

\begin{tabular}{|c|l|l|c|c|l|}
\hline Road no. & \multicolumn{1}{|c|}{ Segment } & Road standard & $\begin{array}{c}\text { Length } \\
\mathbf{( k m )}\end{array}$ & $\begin{array}{c}\text { Investments } \\
\text { needed }\end{array}$ & \multicolumn{1}{|c|}{ Realisation/plans } \\
\hline S61 & $\begin{array}{l}\text { Augustów ring } \\
\text { road (a fragment } \\
\text { is a part of S61) }\end{array}$ & Provincial road & 12.8 & S2x2 & Opened in November 2014 \\
\hline DK8/S61 & $\begin{array}{l}\text { Suwałki ring } \\
\text { road }\end{array}$ & $\begin{array}{l}\text { Two-way } \\
\text { national road }\end{array}$ & 12.8 & S2x2 & $\begin{array}{l}\text { Tender to be potentially announced } \\
\text { at the turn of 2015. Planned realisa- } \\
\text { tion in the years 2015-2018 }\end{array}$ \\
\hline DK8/S61 & Suwałki-Budzisko & $\begin{array}{l}\text { Two-way } \\
\text { national road }\end{array}$ & 24.0 & S2x2 & $\begin{array}{l}\text { Design work. Stage of societal } \\
\text { consultations. Tender planned for } \\
\text { 2015. Expected opening until 2020. }\end{array}$ \\
\hline
\end{tabular}

Source: own elaboration.

On the other hand, the intensity of traffic on the road segment opened in 2009 between Radzymin and Wyszków shall be heavily influenced by the administrative decisions, concerning the movement of heavy good vehicles over the expressway S8 through Warsaw, and, potentially by the projects related to the so-called big ring road of Warsaw in its northern fragment, that is - on the national road no. 62 between Wyszków and Nowy Dwór Mazowiecki. In 2014, depending upon the traffic situation in the capital city (limitations, associated, in particular, with the realisation of the projects along the route of S8, e.g. on Grot-Rowecki Bridge), the transit traffic flow, which omits Warsaw, has been taking advantage, to a bigger or lesser extent, of the so-called outer ring road, following the roads DK50 and D62. The intensity of traffic on the fragment of the outer ring road from Wyszków through Serock, Nowy Dwór Mazowiecki, Wyszogród, and Sochaczew, to the motorway A2 in Żyrardów (the node of Wiskitki) and to the road S8 in Mszczonów, has been systematically increasing in the years 2000-2010 (which is also expressed through the visible decrease of the heavy good vehicles traffic intensity on the analysed fragment of the route, between Radzymin and Wyszków). The ring roads of Mszczonów, Żyrardów, Słomczyn, Chynów, and the node in Mińsk Mazowiecki have been built. These statements concern, in principle, uniquely the heavy good vehicles traffic. The traffic of passenger cars, including the job-commuting-related traffic, has been intensifying in the years 2000-2010, reaching more than 21000 vehicles per day on the ring road of Radzymin (Table 6 and Fig. 14). The smoothness of traffic in commuting to Warsaw over this particular direction shall be improved by the realisation of the ring road of Marki from the node of Marki to Radzymin. At the end of the year 2014 this fragment of $15 \mathrm{~km}$ of length has been subject to tender. Termination of works is planned for the year 2019. 
Table 7. Traffic intensity in 2010 on the segment of the national road no. 8 between Augustów and the state boundary in Budzisko, and between Radzymin and Wyszków

\begin{tabular}{|c|c|c|c|c|c|c|c|c|c|}
\hline $\begin{array}{c}\text { Road } \\
\text { no. }\end{array}$ & $\begin{array}{c}\text { Length } \\
(\mathrm{km})\end{array}$ & Segment & $\begin{array}{l}\text { Total of } \\
\text { vehicles }\end{array}$ & $\begin{array}{l}\text { Motor- } \\
\text { cycles }\end{array}$ & $\begin{array}{c}\text { Passen- } \\
\text { ger cars, } \\
\text { micro- } \\
\text { buses }\end{array}$ & $\begin{array}{c}\text { Light } \\
\text { trucks } \\
\text { (delivery } \\
\text { vans) }\end{array}$ & $\begin{array}{c}\text { Heavy } \\
\text { good } \\
\text { vehicles } \\
\text { without } \\
\text { trailers }\end{array}$ & $\begin{array}{c}\text { Heavy } \\
\text { good } \\
\text { vehicles } \\
\text { with } \\
\text { trailers }\end{array}$ & Coaches \\
\hline \multicolumn{10}{|c|}{ National road no. 8 Augustów-state boundary in Budzisko } \\
\hline 8 & 1.0 & Augustów /passage 1/ & 17215 & 85 & 10854 & 1253 & 718 & 4136 & 143 \\
\hline 8 & 2.4 & Augustów /passage 2/ & 18752 & 86 & 12015 & 1341 & 540 & 4544 & 211 \\
\hline 8 & 2.5 & Augustów /passage 3/ & 17767 & 91 & 11282 & 1263 & 633 & 4306 & 181 \\
\hline 8 & 10.7 & Augustów-Olszanka & 11621 & 28 & 5789 & 851 & 399 & 4474 & 76 \\
\hline 8 & 10.6 & Olszanka-Suwałki & 10658 & 25 & 4879 & 891 & 334 & 4440 & 82 \\
\hline 8 & 13.2 & Suwałki-Szypliszki & 8358 & 29 & 3532 & 549 & 240 & 3944 & 57 \\
\hline 8 & 7.1 & $\begin{array}{l}\text { Szypliszki-state } \\
\text { boundary }\end{array}$ & 7207 & 23 & 2530 & 468 & 206 & 3931 & 45 \\
\hline \multicolumn{10}{|c|}{ National road no. 8 Radzymin-Wyszków } \\
\hline S8 & 5.7 & Radzymin /ring road/ & 21043 & 53 & 16192 & 1719 & 949 & 1710 & 419 \\
\hline S8 & 3.4 & $\begin{array}{l}\text { Radzymin-Wola } \\
\text { Rasztowska }\end{array}$ & 22876 & 56 & 17289 & 2266 & 1012 & 1760 & 490 \\
\hline $\begin{array}{c}\text { S8 } \\
\text { S8d }\end{array}$ & 18.8 & $\begin{array}{l}\text { Wola } \\
\text { Rasztowska-Lucynów }\end{array}$ & 23207 & 70 & 17897 & 2198 & 823 & 1750 & 468 \\
\hline S8d & 4.3 & Wyszków ring road 1 & 14854 & 47 & 10941 & 1497 & 769 & 1458 & 142 \\
\hline S8d & 3.7 & Wyszków ring road 2 & 13669 & 40 & 10026 & 1339 & 619 & 1511 & 133 \\
\hline
\end{tabular}

Source: own elaboration.
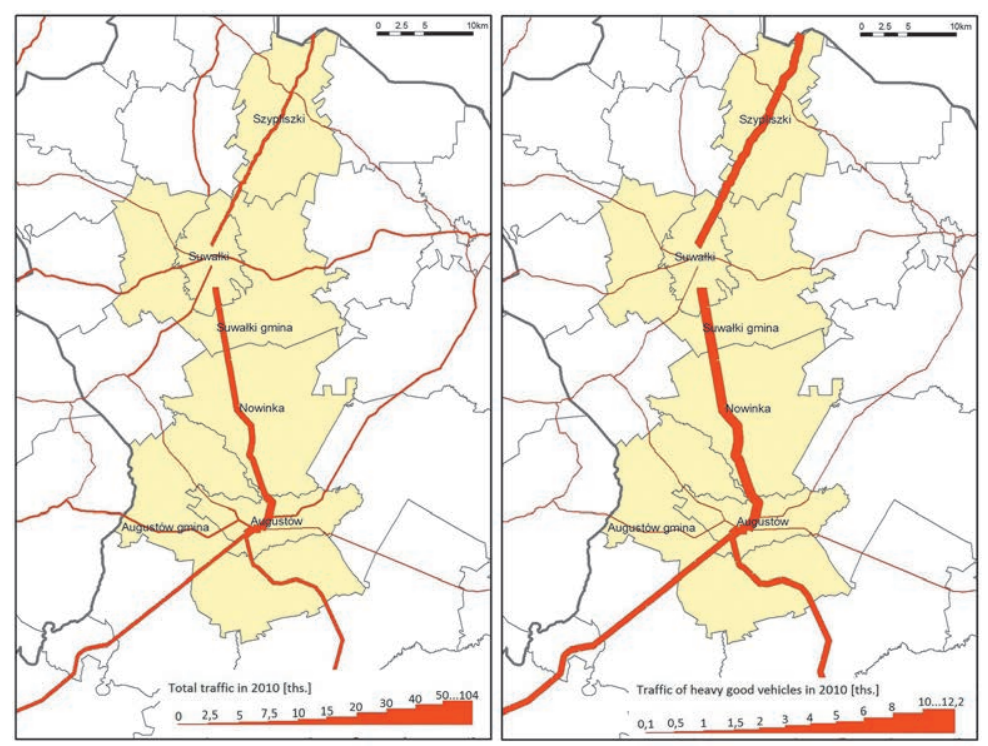

Figure 11. Traffic intensity - total and of the heavy good vehicles - in 2010 on the national road no. 8 between Augustów and the state boundary in Budzisko Source: own elaboration on the basis of GPR 2010. 

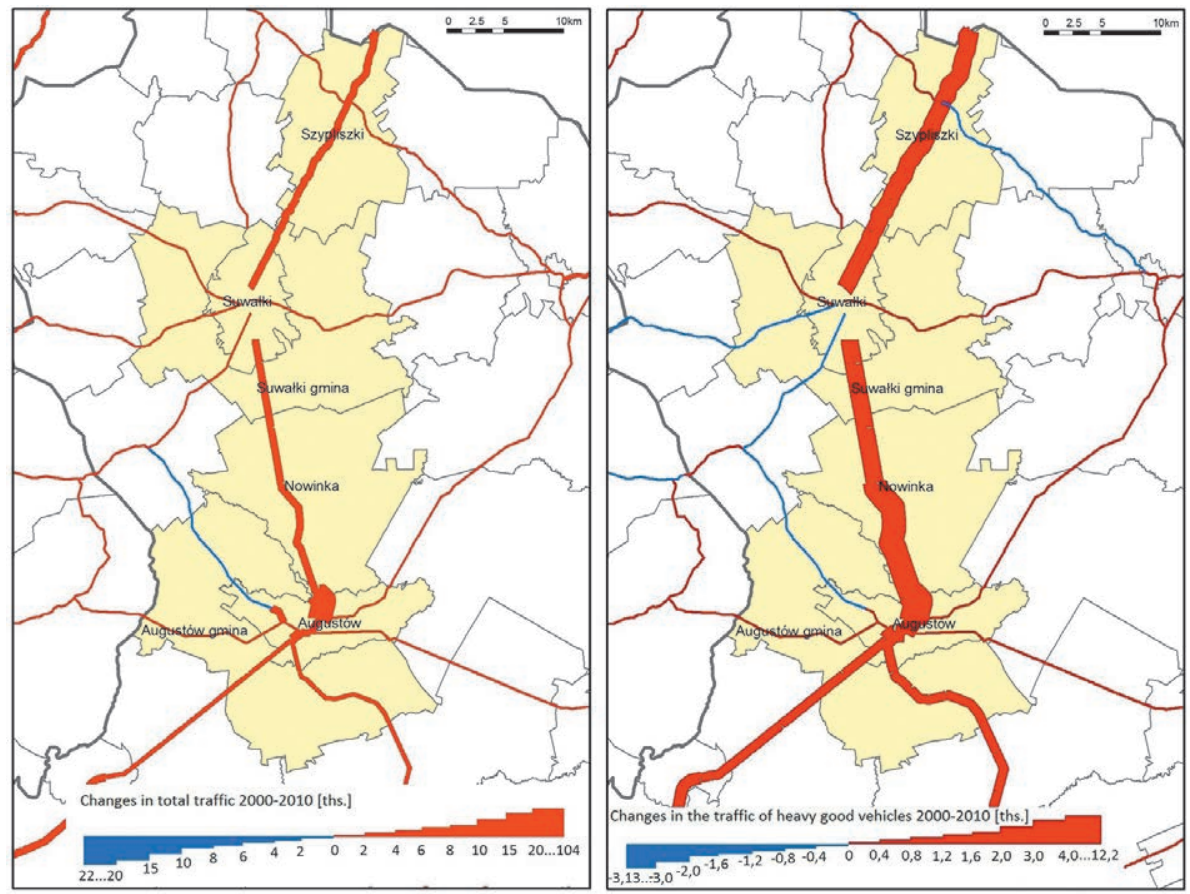

Figure 12. Changes in traffic intensity - total traffic and traffic of heavy good vehicles - in the years 2000-2010 on the national road no. 8 between Augustów and the state boundary in Budzisko Source: own elaboration on the basis of GPR 2000 and GPR 2010.
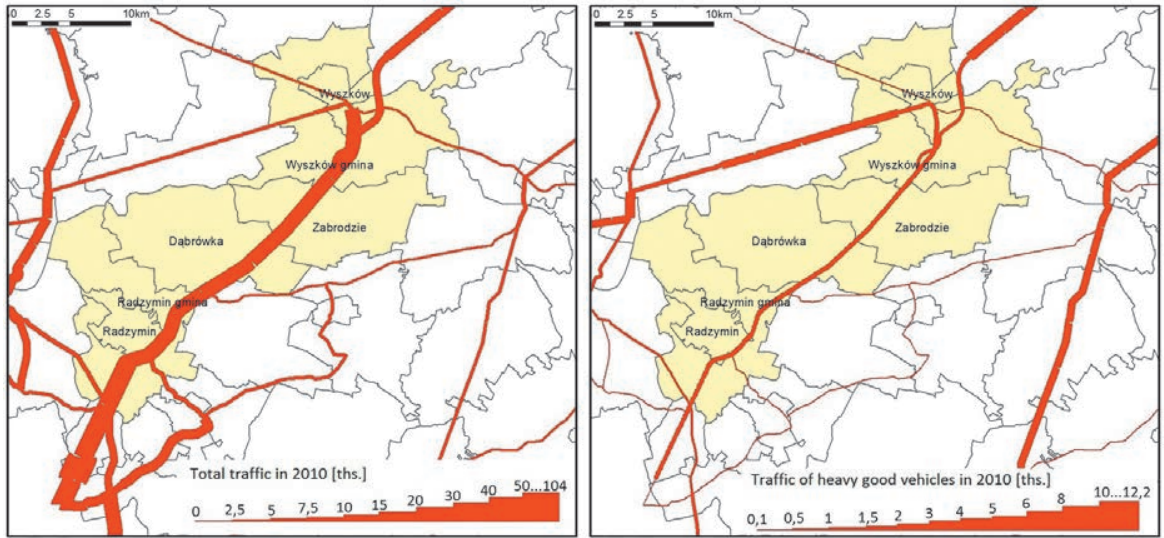

Figure 13. Traffic intensity - total and of the heavy good vehicles - in 2010 on the national road no. 8 between Radzymin and Wyszków

Source: own elaboration on the basis of GPR 2010. 

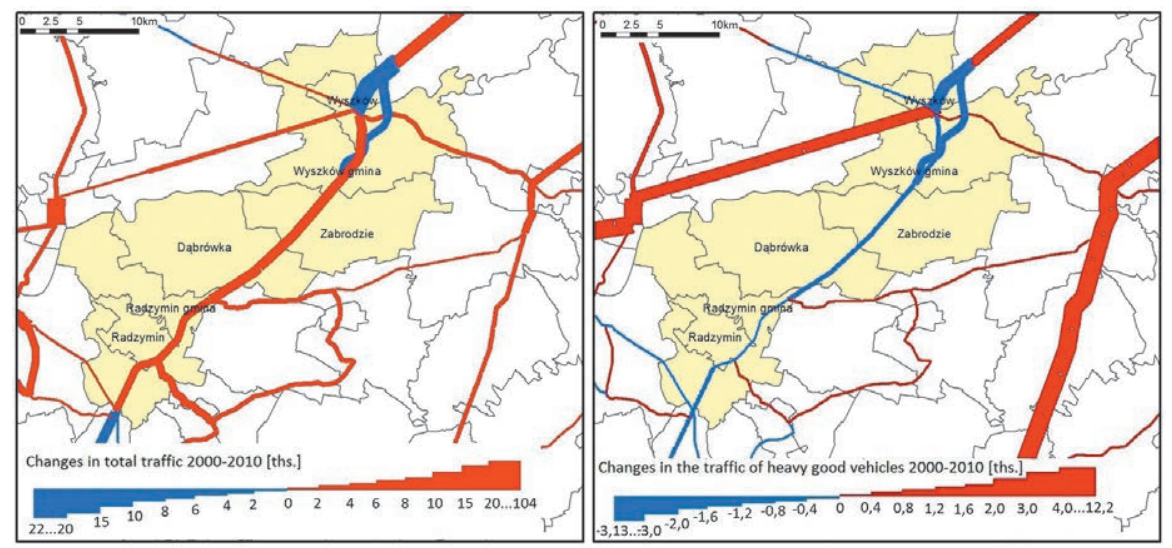

Figure 14. Changes in traffic intensity - in total and of the heavy good vehicles - in the years 2000-2010 on the national road no. 8 between Radzymin and Wyszków

Source: own elaboration on the basis of GPR 2000 and GPR 2010.

\section{Traffic intensity on the national road no. 17 between Garwolin and Kurów}

The province of Lublin has been until now the region of Poland, where road-wise accessibility improved the least. The sole project, realised in the period 2000-2010 regarding the key functional connection between Warsaw and Lublin over the national road no. 17, of which the here analysed case study is a fragment, was the ring road of Garwolin, having $13 \mathrm{~km}$ of length, which was opened in 2007. The essential projects, concerning the functional connection between Warsaw and Lublin, were carried out only in the years 2013-2014, when a fragment of the expressway S17 was opened between Kurów and Lublin.

In the context of the planned road projects it should be noted that at the end of 2013 the tender was announced according to the formula "design \& construct" for the execution of four segments of S17, having total length of $58.6 \mathrm{~km}$, within the fragment Garwolin-Kurów. Currently, the verification is underway of the applications, filed by the entities, interested in constructing the particular segments of the road.

Traffic intensity on the analysed segment of the road is more or less constant, and amounted in 2010 to 11-14 000 vehicles per day, including 1500-2 100 trucks (see Table 8). In the years 2000-2010 an increase of the traffic intensity was taking place, both in total, and of the heavy good vehicles traffic, although this increase was not as spectacular as in the other case studies here presented (Figs. 15 and 16). 
Table 8. Traffic intensity over the segment of the national road no. 17 between Garwolin and Kurów in 2010

\begin{tabular}{|c|c|c|c|c|c|c|c|c|c|}
\hline $\begin{array}{c}\text { Road } \\
\text { no. }\end{array}$ & $\begin{array}{c}\text { Length } \\
\text { (km) }\end{array}$ & Segment & $\begin{array}{l}\text { Total of } \\
\text { vehicles }\end{array}$ & $\begin{array}{c}\text { Motor- } \\
\text { cycles }\end{array}$ & $\begin{array}{c}\text { Passen- } \\
\text { ger cars, } \\
\text { micro- } \\
\text { buses }\end{array}$ & $\begin{array}{c}\text { Light } \\
\text { trucks } \\
\text { (delivery } \\
\text { vans) }\end{array}$ & $\begin{array}{c}\text { Heavy } \\
\text { good } \\
\text { vehicles } \\
\text { without } \\
\text { trailers }\end{array}$ & $\begin{array}{c}\text { Heavy } \\
\text { good } \\
\text { vehicles } \\
\text { with } \\
\text { trailers }\end{array}$ & Coaches \\
\hline S17 & 1.8 & Garwolin /ring road 1/ & 13296 & 46 & 9832 & 1157 & 549 & 1640 & 71 \\
\hline S17 & 7.6 & Garwolin /ring road 2/ & 13009 & 38 & 8837 & 1251 & 895 & 1893 & 95 \\
\hline $\begin{array}{c}\text { S17/ } \\
17\end{array}$ & 10.4 & Garwolin-Gończyce & 14162 & 55 & 10581 & 1266 & 602 & 1453 & 196 \\
\hline 17 & 18.6 & Gończyce-Ryki & 12873 & 60 & 9492 & 1212 & 526 & 1401 & 165 \\
\hline 17 & 7.5 & Ryki /passage/ & 14024 & 68 & 10184 & 1467 & 626 & 1453 & 202 \\
\hline 17 & 13.5 & Moszczanka-Żyrzyn & 12341 & 40 & 8769 & 1268 & 612 & 1482 & 162 \\
\hline 17 & 14.6 & Żyrzyn-Kurów & 11848 & 35 & 7813 & 1198 & 539 & 2143 & 111 \\
\hline
\end{tabular}

Source: own elaboration.
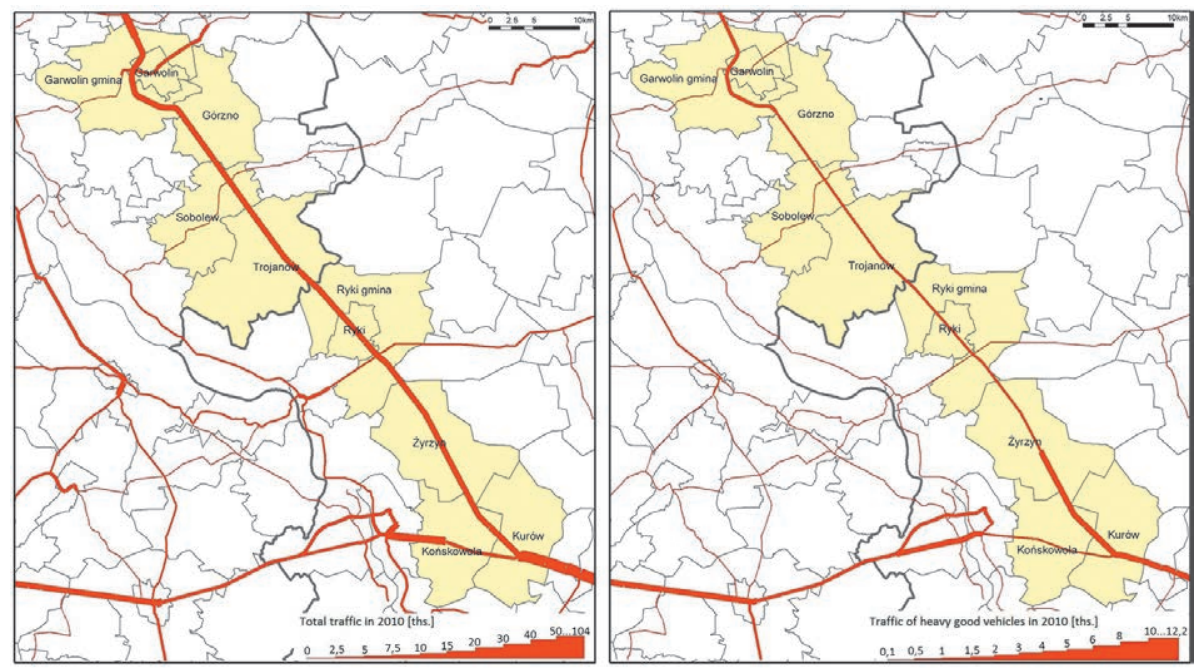

Figure 15. Traffic intensity in total and of the heavy good vehicles in 2010 on the national road no. 17 between Garwolin and Kurów

Source: own elaboration on the basis of GPR 2010. 

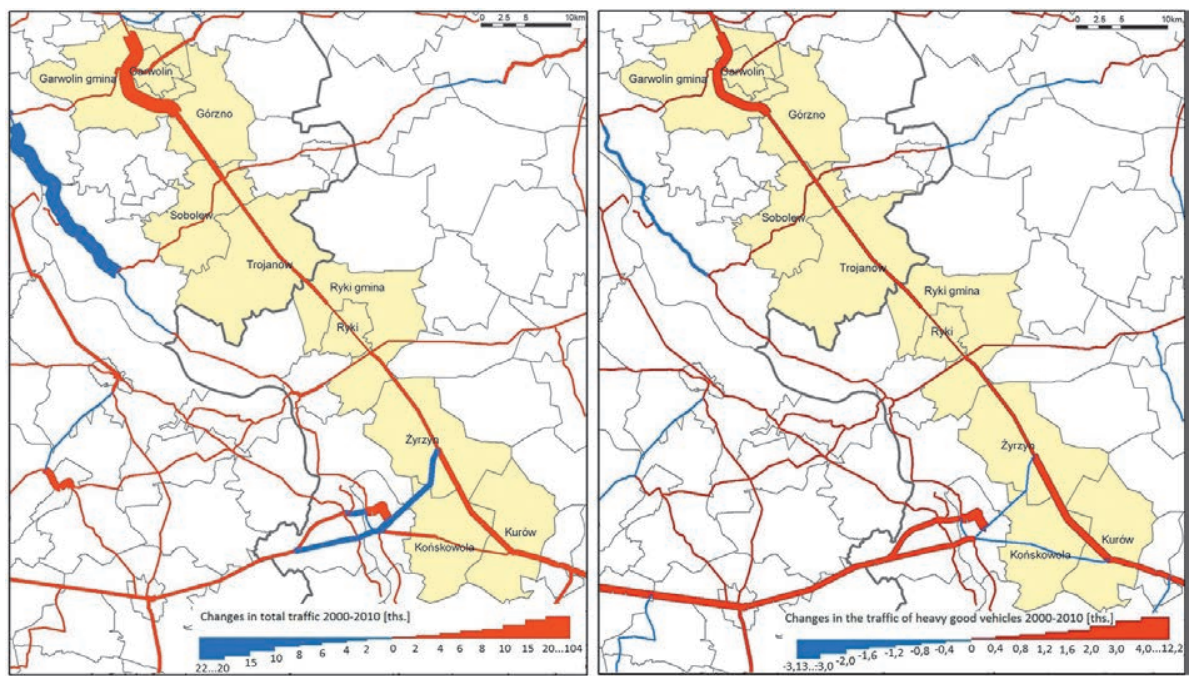

Figure 16. Changes in traffic intensity in total and of the heavy good vehicles in the years 2000-2010 on the national road no. 17 between Garwolin and Kurów

Source: own elaboration on the basis of GPR 2000 and GPR 2010.

\section{Conclusions}

An abrupt increase of the car numbers and the initiation of the intensive structural undertakings, aiming at the improvement of the conditions of car travelling, including construction of motorways and expressways, resulted in a significant increase of road traffic intensity in Poland (Rosik 2012; Komornicki et al. 2013; Rosik \& Stępniak 2015). Opening of a motorway or of an expressway brings about a shift of a part of traffic flow, especially of the transit traffic, from the parallel national roads onto the newly built segments. The drivers of the passenger cars achieve almost doubling of the travel speed over a given connection after a motorway is opened (e.g. over the motorway connections Wrocław-Opole or Gdansk-Grudziądz). Hence, the motorways have an important competitive advantage, time-wise, in comparison with the parallel national roads. The situation gets more complex when the toll payment is introduced, this toll ranging on the road segments analysed (in 2012) from $0.10 \mathrm{PLN} / \mathrm{km}$ between Wrocław and Opole to $0.16 \mathrm{PLN} / \mathrm{km}$ between Gdansk and Grudziądz.

In spatial terms, concentration is observed in Poland of the traffic of passenger cars on the routes of the motorways and expressways, and on the entry roads to the agglomerations. An even bigger concentration on the motorway routes is observed for the truck traffic. At the same time, a visible decrease takes place of the truck traffic on the national roads, parallel to the motorways (DK91 and DK94). In the traffic of heavy good vehicles, the motorway corridors are very pronounced, first of all the southern corridor of the motorway A4. The diagonal pattern from the boundary with Czechia through Upper Silesia and Warsaw in the direction of the boundary with Lithuania at Budzisko is also increasingly visible. The latter setting contains also the here analysed border-adjacent case studies on the national road no. 8 between Kudowa Zdrój and Wrocław, and between Augustów and Budzisko. An important influence is exerted on the changes in traffic intensity by the local factors, like, for instance, ban on truck traffic during definite hours in Warsaw, which has entailed the increase of 
the truck traffic on the so-called big ring road of Warsaw and the decrease of the truck traffic, in the years 2000-2010, on the entry roads to the capital city, observed in the framework of the case study of the expressway S8 between Radzymin and Wyszków.

\section{References}

Generalny Pomiar Ruchu, 2000. Generalna Dyrekcja Dróg Krajowych i Autostrad.

Generalny Pomiar Ruchu, 2010. Generalna Dyrekcja Dróg Krajowych i Autostrad.

Komornicki T., Rosik P., Śleszyński P., Solon J., Wiśniewski R., Stępniak M., Czapiewski K., Goliszek S., 2013. Wplyw budowy autostrad i dróg ekspresowych na rozwój społeczno-gospodarczy i terytorialny Polski. Warszawa: Ministerstwo Rozwoju Regionalnego.

Rosik P., 2012. Dostępność lądowa przestrzeni Polski w wymiarze europejskim. Prace Geograficzne, no. 233, Warszawa: Instytut Geografii i Przestrzennego Zagospopdarowania PAN, 307 pp.

Rosik P., 2014. Zrównoważony transport lądowy a przesunięcie modalne w latach 2000-2010 - ujęcie przestrzenne. Logistyka, 2, pp. 274-284.

Rosik P., Kowalczyk K., 2015. Rozwój infrastruktury drogowej i kolejowej a przesunięcia modalne w Polsce w latach 2000-2010, Prace Geograficzne IGiPZ PAN, Warszawa, 248, 215 pp.

Rosik P., Kowalczyk K., Stępniak M., Goliszek S., Komornicki T., 2014. Bazy danych potoków ruchu-monitoring przestrzenny w latach 2000-2010 (projekt TRRAPS XXI). [in:] Modelowanie podróży i prognozowanie ruch. Zeszyty Naukowo-Techniczne Stowarzyszenia Inżynierów Komunikacji RP, Kraków, pp. 303-316.

Rosik P., Stępniak M., 2015. Monitoring of changes in road potential accessibility at municipality level in Poland 1995-2015, Geographia Polonica, vol. 88, 4, pp. 607-620. 